\title{
Redes neurales artificiales y toxicodependencias
}

\author{
Buscema M.
}

Director del Centro Ricerche di Scienze della Camunicazione

Enviar correspondencia a:

Viale di Val Fiorita, 88 - 00144 Roma, Italia. Tel. ++39-06-5923622 - Fax: ++39-06-5920261

e-mail: semeion@ats.it - semeion.ricerca@agora.stm.it. Internet: www.semeion.it

\section{Resumen.}

Las redes neurales artificiales (RNAs) pertenecen a la amplia área de la Computación natural, que es una importante disciplina de las ciencias artificiales. En la Computación natural cada técnica trata de llevar a cabo un proceso de aprendizaje: mira a los datos que se deben estudiar muchas veces, tratando cada vez de minimizar los errores de la última vez. La Computación natural es el área donde los científicos crean los Sistemas Artificiales Adaptativos. Los RNAs representan dentro de la Computación natural a una amplia familia de poderosas técnicas, cuyo objetivo es 'aproximar' los parámetros de cualquier tipo de función matemática continua. Esto significa que los RNAs son capaces de computar funciones no lineares muy complejas.

Desde un punto de vista práctico ello significa que las RNAs son instrumentos muy útiles para la clasificación inteligente, la predicción temporal, reagrupamientos naturales y asociaciones inteligentes y dinámicas. Las RNAs son por descontado muy distintas unas de otras, teniendo cada una su especificidad individual, que da cuenta de sus capacidades y limitaciones. La habilidad del profesional está en conseguir utilizar la RNA más adecuada para un problema específico.

En el campo social las RNAs han sido poco utilizadas. Ello se debe muchas veces a la escasa financiación, pero también a que los profesionales de lo social están demasiado implicados en las creencias sobre su campo. Es por ello que muchas veces prefieren ser emocionalmente felices que estar científicamente en lo correcto.

Palabras clave: Inteligencia artificial, Redes neurales artificiales, campo social

\section{Summary.}

Artificial Neural Networks (ANNs) belong to the wide area of Natural Computation, a new important discipline of Artificial Sciences. In Natural Computation each technique try to implement a learning process: look at the data representing the problem many times, each time trying to minimize the errors of the last time. Natural Computation is the area where scientist create Artificial Adaptive Systems. ANNs represent in Natural Computation a wide family of powerful techniques, whose goal is to "aproximate" the parameters of any kind of mathematical continuos function. That means the ANNs are able to compute also very complex non linear function.

From a practical point of view, that means that ANNs are very useful tools for intelligent classification, temporal prediction, natural clustering and intelligent and dynamic associations. ANNs, of course, are very different each other. Each ANN is a specific individual with specific capabilities and weakness. Scientist ability is to match the specific problem with the right ANN.

In the social field ANNs were used seldom. That's for many reasons: in social field there is few money, and social scientists are too much involved in what they believe about their field. So many times they prefer to be emotionally happy, than scientifically right.

Key words: Artificial intelligence, Artificial Neural Networks, social field

El creciente éxito de las RNA se debe a su capacidad como herramientas matemáticas e informáticas, especialmente adecuadas para la comprensión y la previsión de la dinámica de fenómenos complejos.

Como están inspiradas en el funcionamiento del cerebro humano, los investigadores son conscientes de que su potencia metodológica está conectada a la existencia de una teoría del cerebro subyacente, muy compleja y prometedora. 
Su fuerza matemática y su inspiración biológica han contribuido en los últimos años a encaminar el mundo de las RNA en dos direcciones bastante distintas:

a. El estudio y la creación de nuevos modelos de RNA que permitan explorar el funcionamiento de algunas partes del cerebro humano. La tesis de estas investigaciones es sencilla: la comprensión científica de un fenómeno (el cerebro y su funcionamiento) está conectada a la capacidad de simularlo, aunque sea parcialmente, con instrumentos artificiales: conozco aquello que puedo crear de nuevo.

b El uso de las RNA en campos sumamente complejos en los que se considera prácticamente ineficaz el uso de herramientas tradicionales como la estadística clásica, los sistemas expertos, etc. Esta vía de investigación, en un primer momento, fue utilizada de una manera muy ingenua, y las RNA se usaron como si fuesen instrumentos mágicos capaces de encontrar la solución de cualquier problema, aplicándolas como una medicina omnipotente. En un segundo momento (a partir del año 92 en adelante) se inició un uso más prudente y realista de estas técnicas, definiéndose los protocolos de proyectación de las RNA propiamente dichas:

1. Definición del problema a tratar.

2. Selección de las variables que representen el problema.

3. Definición de la muestra de datos y su análisis.

4. Operaciones de preprocessing sobre datos reales.

5. Selección de las arquitecturas de RNA más adecuadas para cada tipo de problema.

6. Hibridaciones ocasionales de las RNA seleccionadas con otras técnicas de análisis.

7. Test de validación de las arquitecturas seleccionadas.

8. Etc.

La difusión y el uso de las RNA como herramientas para la resolución de problemas reales ha seguido las típicas pautas de la cultura occidental: primero llegó a los sectores de mayor rentabilidad política y/o económica (militar, financiero, industrial, etc.), y después a los otros (y estos casos, muchas veces, muy despacio).

En este sentido, hay que señalar que el sector socio-sanitario apenas si figura en la lista de este implícito marketing científico. Al fin y al cabo, no creo que resulte exagerado afirmar que la toxicodependencia suele considerarse, en casi todos los cuadros, algo que genera más gastos que beneficios. De hecho, es más que probable que el uso de estas técnicas de previsión tan poderosas se encuentre ya mucho más difundido entre los gestores de los mercados de la droga que en los ámbitos preocupados por su curación.

Todo esto, en definitiva, debería hacernos recapacitar sobre si no iría siendo hora de que empezásemos a considerar la vida más remuneradora que la muerte o el dinero. Pero en nuestra cultura, esto es una utopía; es decir, una cosa que se dice, pero que no se hace.

Paradójicamente, el mundo de las RNA se presta mejor para la comprensión de fenómenos bio-sociales que para la previsión de los procesos de control industrial. Y esto se debe a distintas razones:

1. Las RNA son herramientas capaces de comprender la dinámica de procesos extremadamente no lineales; es bien sabido que la banalidad de la relación causa $\mathbb{E}$ efecto es uno de los puntos débiles de los análisis sociales.

2. Las RNA son herramientas que no fuerzan a que los datos sigan las reglas de su modelo. Por el contrario, lo que hacen es crear unas reglas difuminadas y repartidas que explican mejor los datos iniciales. De hecho, una RNA no es un modelo, sino un Generador de Modelos.

3. Las RNA se adaptan a los datos según una dinámica bottom-up. La complejidad de un fenómeno, por tanto, surge espontáneamente de la interacción de sus componentes elementales. Por el contrario, las herramientas más tradicionales de análisis aprisionan los datos en hipótesis construidas desde arriba (top-down dynamics).

4. Las RNA procesan todas las variables de una base de datos en paralelo y sin límites cardinales. Por el contrario, muchas herramientas tradicionales fuerzan a los investigadores a limitar y/o agregar de modo arbitrario las variables disponibles, o a considerarlas en bloque, o también, a establecer hipótesis de correlación de escaso fundamento.

5. Las RNA ajustan sus reglas en el tiempo espontáneamente; simplemente, a medida que cambian los datos que se introducen. Esto quiere decir que aprenden. Y por ello resulta posible que se puedan simular escenarios hipotéticos según dinámicas no lineales. En relación con las herramientas tradicionales representan lo que el cinematógrafo representó para la fotografía.

6. Las RNA están predispuestas estructuralmente para gestionar datos ruidosos, difusos, inciertos y aproximados. Representan una matemática precisa de la incertidumbre, al contrario de muchas técnicas conocidas, que funcionan inspirándose en una vaga matemática de lo obvio. 
Estas son algunas de las características que hacen que las RNA sean herramientas especialmente adecuadas para el análisis de los comportamientos humanos y sociales.

Pero su propia fuerza, sin embargo, esconde algunos peligros.

Las RNA son herramientas muy complejas de proyectar. Más del 90\% del software disponible que ofrece RNA resulta menos valioso que el uso inteligente de los software de estadística de buena calidad.

Además, muchas multinacionales expertas en software estadístico han incorporado, por problemas de mercado, librerías software con RNA. La inexperiencia de este sector de empresas expertas en estadística, pero que no conocen el mundo de las RNA, ha generado muchos "pastiches".

Para quien no las conoce, o las conoce poco, las RNA son herramientas que sólo presentan una o dos variantes. Pero en realidad, las RNA constituyen todo un mundo de arquitecturas y modelos matemáticos, cada uno con sus propias características específicas, que muchas veces son irreductibles entre sí, incluso en términos de prestaciones.

Las RNA son herramientas que requieren un modo de concebir los datos muy distinto a como se conceptualizan en el campo de la estadística tradicional: aprender a traducir un problema real en un problema a través de RNA es una tarea compleja, y requiere que el investigador la conozca.

Sin la adquisición de los conocimientos pertinentes, el investigador se vería como quien quiere evaluar las prestaciones del motor de un Ferrari en un camino equivocado.
En definitiva, las RNA son una familia de herramientas extremadamente potentes y útiles en el ámbito social y socio-sanitario, pero que requieren, por parte del usuario inteligente, un conocimiento profundo y específico (aunque no necesariamente de tipo matemático).

Los ámbitos del mundo social en los que su planteamiento y su uso es deseable son muy numerosos:

- desde la personalización de los procesos terapéuticos hasta la previsión de vulnerabilidad hacia varios tipos de drogas;

- desde la planificación de servicios socio-sanitarios, hasta la simulación del impacto de las campañas de prevención sobre realidades territoriales específicas;

- desde la verificación de los proyectos terapéuticos hasta la simulación de los efectos de algunas leyes sobre el comportamiento tóxico dependiente.

- desde la previsión de recaídas en el uso de drogas hasta la generación de tipologías dinámicas de toxicodependencia.

Sin embargo, estas posibilidades son tan amplias como potenciales.

Su actualización está relacionada con una variable que actualmente ni siquiera es procesable mediante el uso de RNA, y esta variable en cuestión es la siguiente: ¿hasta qué punto los trabajadores del sector social están dispuestos a contemplar la desaparición de las hipótesis a las que están habituados? ¿Hasta qué punto estamos dispuestos a reducir nuestra centralidad política para contribuir a que aumente nuestra utilidad social? 